\title{
HUBUNGAN ANTARA PEMANFAATAN E-JOURNAL DAN MOTIVASI BELAJAR DENGAN KEMAMPUAN PENGETAHUAN KEPUSTAKAAN
}

10.34005/akademika.v8i02.545

\author{
Astrid Natasya Rachmatia \\ Nat_tasya19@yahoo.com \\ Universitas Islam As-Syafi'iyah Jakarta \\ Indonesia
}

\author{
Khasanah \\ Khasanahrcl.mtp@uia.ac.id \\ Universitas Islam As-Syafi'iyah Jakarta \\ Indonesia
}

\begin{abstract}
Abstrak:Penelitian ini bertujuan untuk meneliti 1). Hubungan antara pemanfaatan EJournal dengan kemampuan pengetahuan kepustakaan, 2). Hubungan antara motivasi belajar dengan kemampuan pengetahuan kepustakaan, 3), Hubungan antara pemanfaatan E-Journal dan motivasi belajar secara bersama-sama dengan kemampuan pengetahuan kepustakaan. Hipotesis dari penelitian ini adalah 1). Diduga terdapat hubungan positif antara pemanfaatan E-Journal dengan kemampuan pengetahuan kepustakaan, 2). Diduga terdapat hubungan positif antara motivasi belajar dengan kemampuan pengetahuan kepustakaan, 3), Diduga terdapat hubungan positif antara pemanfaatan E-Journal dan motivasi belajar secara bersama-sama dengan kemampuan pengetahuan kepustakaan. Hasil penelitian menunjukkan bahwa 1). Hipotesis pertama diterima, bahwa terdapat hubungan positif antara pemanfaatan E-Journal dengan kemampuan pengetahuan kepustakaan, 2). Hipotesis kedua ditolak, karena dari hasil pengujian dibuktikan bahwa tidak terdapat hubungan antara motivasi belajar dengan kemampuan pengetahuan kepustakaan, 3). Hipotesis ketiga diterima, bahwa terdapat hubungan positif antara pemanfaatan E-Journal dan motivasi belajar secara bersamasama dengan kemampuan pengetahuan kepustakaan dengan tingkat koefisien rendah.
\end{abstract}

Kata Kunci: Pemanfaatan E-Journal, Jurnal Elektronik, Motivasi Belajar, Kemampuan Pengetahuan Kepustakaan, Perpustakaan.

\begin{abstract}
Abstrac:The research is purposed to examine, 1). A significant relationship between the use of electronic journals and library knowledge, 2). A significant relationship between motivation to learn and library knowledge, 3). A significant relationship between the use of electronic journals and motivation to learn together with library knowledge. The hypothesis of this study is, 1). There is a positive relationship between the use of electronic journals and library knowledge, 2). There is a positive relationship between motivation to learn and library knowledge, 3). There is a positive relationship between the use of electronic journals and motivation to learn together with library knowledge. The result of test showed: 1). The first hypothesis is accepted, there is a positive relationship between the use of electronic journals and library knowledge, 2). The second hypothesis is rejected, because from the test results it can be seen that there is no relationship between motivation to learn and library knowledge, 3). The third hypothesis is accepted, there is a positive relationship between the use of electronic journals and motivation to learn together with library knowledge skills with low coefficient levels.
\end{abstract}

Keyword: Utilization Of Electronic Journal, Electronic Journal, Learning Motivation, Knowledge Ability Literature, Libraries. 


\section{PENDAHULUAN}

Perkembangan ilmu pengetahuan dan teknologi yang semakin pesat tidak bisa dipungkiri sangat mempengaruhi gaya hidup manusia saat ini, termasuk gaya berkomunikasi dan gaya pencarian informasi. Teknologi merupakan sistem yang diciptakan oleh manusia untuk suatu tujuan tertentu. Teknologi adalah kepanjangan dari kemampuan manusia tersebut. Teknologi yang ada, tergantung bagaimana manusia merancang nya, memanfaatkan nya, dan menerima nya. Jadi nilai dari segala bentuk teknologi tergantung pada kegunaannya bagi umat manusia. Seperti hal nya dengan internet. Internet merupakan salah satu bukti nyata adanya perkembangan teknologi dalam hal komunikasi dan informasi. Saat ini banyak orang menggunakan internet untuk berbagai keperluan. Bukan hanya kebutuhan bersosialisasi saja, namun saat ini dunia pendidikan pun sudah merambah kearah kemajuan teknologi. Banyak orang yang memanfaatkan internet ini untuk melakukan pencarian berbagai macam informasi, termasuk kepada para mahasiswa sering melakukan pencarian informasi untuk mengerjakan tugas-tugas perkuliahannya. Mereka sering melakukan pencarian dengan menggunakan fasilitas search engine seperti google, untuk membantu mereka menemukan jawaban dari tugastugas yang diberikan. Namun sayang nya tidak semua informasi yang ada pada google bersifat ilmiah dan dapat dipertanggung jawabkan kebenarannya.

Mahasiswa selaku objek yang akan di didik dan diberikan pengetahuan, hingga dapat dikatakan layak dan kompeten pada satu bidang tertentu, merasa perlu untuk diberikan edukasi untuk dapat memanfaatkan jurnal elektronik tersebut. Setelah mereka diberikan edukasi, diharapkan mereka memiliki kemampuan pengetahuan kepustakaan untuk selanjutnya dapat timbul motivasi belajar dari dalam dirinya. Kemampuan pengetahuan kepustakaan inilah yang akan menjadi bekal bagi mereka untuk dapat mengerjakan tugas-tugas perkuliahan dengan mudah.

Tak dapat dipungkiri bahwa setiap individu memiliki kondisinya masing-masing, dimana kondisi tersebut berperan penting dalam aktivitasnya sehari-hari. Kondisi dari masing-masing individu tersebut merupakan salah satu pemicu timbulnya sebuah motivasi dalam diri seseorang. Motivasi seseorang dalam belajar dapat timbul dari dalam diri sendiri, berupa hasrat dan keinginan berhasil dan dorongan kebutuhan belajar, termasuk juga harapan akan cita-citanya. Selain itu juga motivasi dapat timbul dari luar dirinya seperti adanya penghargaan, lingkungan belajar yang kondusif, dan kegiatan belajar yang menarik. Selain lingkungan belajar yang membuat mereka terpacu untuk terus belajar, sebuah institusi pendidikan juga harus menyediakan sumber-sumber

85 I Akademika Jurnal Teknologi Pendidikan Vol. 08 No. 2 
belajar yang nyaman agar mereka dapat melakukan proses belajar mengajar. Serta meyediakan fasilitas-fasilitas penunjang proses belajar mengajar tersebut, seperti laboratorium dan perpustakaan. Seperti diketahui bersama, sumber belajar dapat berbentuk pesan, orang, bahan, alat, metode atau teknik, dan lingkungan seperti kelas, aula, dan perpustakaan.

Berdasarkan latar belakang di atas, maka penulis tertarik untuk melakukan penelitian dengan Judul "Hubungan Pemanfaatan E-Journal dan Motivasi Belajar Dengan Kemampuan Pengetahuan Kepustakaan Pada Universitas di Wilayah Jakarta Timur (Penelitian Korelasi Pada Universitas Swasta di Lingkungan Wilayah Jakarta Timur)"

Adapun rumusan masalah dalam penelitian ini adalah: 1)Apakah terdapat hubungan positif dan signifikan antara pemanfaatan e-journal dengan kemampuan pengetahuan kepustakaan? 2) Apakah terdapat hubungan positif dan signifikan antara motivasi belajar dengan kemampuan pengetahuan kepustakaan? 3) Apakah terdapat hubungan positif dan signifikan secara bersama-sama antara pemanfaatan e-journal dan motivasi belajar dengan kemampuan pengetahuan kepustakaan?

Adapun tujuan penelitian ini adalah 1) Untuk mengetahui hubungan positif dan signifikan antara pemanfaatan e-journal dengan kemampuan pengetahuan kepustakaan para mahasiswa. 2) Untuk mengetahui hubungan positif dan signifikan antara motivasi belajar dengan kemampuan pengetahuan kepustakaan para mahasiswa. 3) Untuk mengetahui hubungan positif dan signifikan secara bersama-sama antara pemanfaatan e-journal dan motivasi belajar dengan kemampuan pengetahuan kepustakaan para mahasiswa.

Kemampuan merupakan hal yang ada dalam diri seseorang semenjak dia lahir. Namun kemampuan tersebut perlu diasah dan dikembangkan, sehingga menjadi suatu yang bermanfaat. Kemampuan adalah suatu kesanggupan dalam melakukan sesuatu. Menurut Chaplin ability (kemampuan, kecakapan, ketangkasan, bakat, kesanggupan) merupakan tenaga (daya kekuatan) untuk melakukan suatu perbuatan. Sedangkan menurut Robbins (2015:35) kemampuan merupakan kapasitas seorang individu untuk melakukan berbagai macam tugas dalam sebuah pekerjaan. Adapun menurut Sudrajat dalam Sriyanto (2015: 35) ability adalah menghubungkan kemampuan dengan kata kecakapan. Setiap individu memiliki kecakapan yang berbeda-beda dalam melakukan suatu tindakan. Kecakapan ini mempengaruhi potensi yang ada dalam diri individu tersebut. Proses pembelajaran yang mengharuskan siswa mengoptimalkan segala kecakapan yang dimiliki.

Suwardi menjelaskan bahwa manusia memiliki sifat ingin tahu terhadap segala sesuatu. Sesuatu yang ingin diketahui manusia tersebut disebut dengan pengetahuan.

Dalam taksonomi bloom (2018:https://id.wikipedia.org/wiki/ Taksonomi_Bloom ) pengetahuan adalah dasar dari tingkatan dalam ranah kognitif. 
Secara teoritis, menurut taksonomi bloom tujuan pendidikan dibagi kedalam tiga domain, yaitu: (1.) Cognitive domain yang berisi perilakuperilaku yang menekankan aspek intelektual, seperti pengetahuan, pengertian, dan keterampilan berfikir; (2) Affective domain yang berisi perilaku-perilaku yang menekankan aspek perasaan atau emosi, seperti minat, sikap, apresiasi dan cara penyesuaian diri; (3) Psychomotor domain berisi perrilaku-perilaku yang menekankan aspek keterampilan motorik seperti tulisan tangan, mengetik, berenang, dan mengoperasikan mesin. Dari domain-domain tersebut dibagi kembali menjadi beberapa kategori dan subkategori yang berurutan secara hirarkis. Dalam pembahasan penelitian ini, pengetahuan kepustakaan masuk kedalam domain kognitif. Maka peneliti hanya akan membahas mengenai ranah kognitif saja.

Kognitif adalah kemampuan intelektual siswa dalam berfikir, mengetahui dan memecahkan masalah. Menurut Bloom dalam Firdaus (2013:1) segala upaya yang menyangkut aktivitas otak adalah termasuk dalam ranah kognitif. Ranah kognitif berhubungan dengan kemampuan berfikir, termasuk didalamnya kemampuan menghafal, memahami, mengaplikasikan, menganalisis, mensintesa, dan kemampuan mengevaluasi. Dalam ranah kognitif itu terdapat enam aspek atau jenjang proses berfikir, mulai jenjang terendah sampai dengan jenjang yang tertinggi. Dalam berbagai kesempatan, banyak orang menjumpai istilah kepustakaan. Istilah tersebut dalam bahasa inggris disebut dengan bibliography atau references, biasa dijumpai pada akhir sebuah karangan atau sebuah artikel ataupun bagian akhir sebuah buku. Kepustakaan dalam hal ini menurut Basuki (1993:7) memiliki arti daftar buku yang menyangkut suatu karya ataupun daftar buku yang digunakan untuk menyusun karya tulis. Biasanya kepustakaan ini dimuat diakhir tulisan dengan tujuan memberi petunjuk bagi pembaca selanjutnya untuk menelusuri subjek yang bersangkutan dengan menggunakan daftar buku. Ajaran dari kepustakaan ini ialah pengetahuan merupakan akumulasi dari pengetahuan sebelumnya.

Kepustakaan menurut Departemen Pendidikan Nasional (h.1122) adalah buku-buku kesusastraan; daftar kitab yang dipakai sebagai sumber acuan untuk mengarang; semua buku, karangan dan tulisan mengenai suatu bidang ilmu, topik, gejala atau kejadian. Studi kepustakaan juga diartikan oleh Mirzakon (2018:3) merupakan suatu studi yang digunakan dalam mengumpulkan informasi dan data dengan bantuan berbagai macam material yang ada di perpustakaan seperti dokumen, buku, majalah, kisah-kisah sejarah, dsb. 
Maka dapat disimpulkan bahwa kepustakaan atau references atau bibliography adalah daftar buku yang menyangkut suatu karya tulis seseorang yang digunakan sebagai sumber acuan.

Dari rangkaian penjelasan di atas, maka dapat ditarik kesimpulan bahwa kemampuan pengetahuan kepustakaan adalah kecakapan intelektual seseorang untuk mengingat kembali atau mengenali kembali atau mengumpulkan informasi sebuah daftar referensi atau bibliografi atau daftar buku yang menyangkut suatu karya tulis seseorang yang digunakan sebagai sumber acuan.

Pemanfaatan merupakan turunan dari kata manfaat, yaitu guna; faedah. Menurut Davis dan Adam, kemanfaatan merupakan tingkatan dimana seseorang percaya bahwa penggunaan suatu teknologi tertentu akan meningkatkan prestasi orang tersebut. Pengukuran kemanfaatan tersebut berdasarkan frekuensi dan diversitas teknologi yang digunakan. Sedangkan menurut Chin dan Thod dalam Arief (2011:36) kemanfaatan dapat berupa kemanfaatan satu faktor seperti pekerjaan lebih mudah, bermanfaat, meningkatkan produktivitas, efektifitas, dan meningkatkan kinerja pekerjaan.

Reitz (h.564) dalam Online Dictionary of Library Information Science, sumber referensi adalah Any publication used by a reference librarian to provide authoritative information in response to a reference question, including but not limited to reference books, catalog records, printed indexes and abstracting services, and online bibliographic databases. Individuals and services outside the library who can be relied upon to provide authoritative information are considered resources for referral. Publikasi yang digunakan pustakawan sebagai referensi untuk memberikan informasi dalam menanggapi pertanyaan, tidak terbatas hanya buku referensi, tetapi juga catatan katalog, indeks dan abstrak, serta pangkalan data online. Layanan di luar perpustakaan dapat diandalkan untuk memberikan informasi yang dapat dianggap sebagai bahan rujukan.

Jurnal menurut Departemen Pendidikan Nasional (h.594) merupakan bagian dari jenis terbitan berseri yang menjadi koleksi perpustakaan. Menurut bahasa jurnal adalah catatan harian, surat kabar khusus. Menurut istilah, jurnal disebutkan oleh Lasa HS (1999:12) adalah terbitan berkala yang berisi tulisan ilmiah yang diterbitkan pada waktu tertentu, tulisan ini biasanya berupa hasil penelitian, artikel ilmiah, maupun ringkasan karya akademik. Adapun pengertian jurnal menurut High Beam dalam Rusydi (08(02):201) "Journal is the collection and periodic publication or transmission of news and the result of research through media", artinya bahwa jurnal merupakan suatu koleksi dan terbitan berkala atau transmisi mengenai berita dan hasil-hasil penelitian mengenai media.

Menurut Handoko seperti dikutip oleh Kurniasari (2014:14) dalam skripsi Pemanfaatan Jurnal Elektronik terhadap Pemustaka Di Perpustakaan Universitas Gadjah Mada Yogyakarta, pemanfaatan jurnal yang merupakan salah satu bahan pustaka koleksi dari perpustakaan jika 
dilihat dari sisi pengguna dipengaruhi oleh faktor internal dan eksternal. Faktor internal meliputi: (1) kebutuhan, (2) motivasi, (3) minat; sedangkan faktor eksternal meliputi: (1) ketersediaan fasilitas pencarian temu kembali informasi, (2) kelengkapan koleksi, (3) keterampilan pustakawan dalam melayani pengguna perpustakaan.

E-journal menurut Andrianty (2005:26) dapat dibedakan menjadi 2 kelompok dari segi akses, yaitu: (1) jurnal elektronik dapat diakses tanpa adanya biaya dan dapat didownload lalu dicetak dengan bebas (open access); (2) jurnal elektronik tidak dapat diakses bila tidak melanggannya dan menggunakan password untuk mengaksesnya (closed access). Pendapat lain tentang jenis jurnal elektronik, yaitu: (1) jurnal yang terbit hanya dalam bentuk elektronik (electronic-only journal); (2) jurnal versi elektronik dengan versi cetakannya.

Kurniasari kembali menegaskan (2014:202) bahwa Jurnal merupakan representasi dari pengetahuan baru tentang perkembangan ilmu pengetahuan yang dilaksanakan secara empiris dan biasanya merupakan gagasan yang terbaru. Sedangkan untuk mendefinisikan lebih lanjut tentang jurnal elektronik atau e-journal adalah jurnal yang segala aspek (penyiapan, review, penerbitan, dan penyebaran) dilakukan secara elektronik. Latar belakang yang memunculkan jurnal elektronik adalah mahalnya percetakan jurnal, kemajuan teknologi komputer dan meluasnya teknologi jaringan www (world wide web). Reitz dalam Kurniasari (2014:202) mendefinisikan bahwa jurnal elektronik sebagai versi digital dari jurnal tercetak, atau jurnal seperti dalam bentuk publikasi elektronik tanpa versi tercetaknya, tersedia melalui email, web atau akses internet. Baik online journal maupun jurnal tercetak merupakan jurnal dalam cakupan terbitan berseri. Perbedaannya terletak pada media aksesnya dimana jurnal tercetak dalam bentuk tercetak berbahan baku kertas dan dibaca langsung, sedangkan online journal berupa jurnal dalam bentuk digital dan untuk membacanya diperlukan akses internet terlebih dahulu. Sedangkan pemanfaatan jurnal elektronik menurut Azwar (2017: 8) seperti terdapat dalam jurnal libraria merupakan kegiatan pemustaka dalam menggunakan jurnal dalam hal mencari informasi yang dibutuhkan. Dari beberapa pengertian di atas maka dapat disimpulkan bahwa pemanfaatan jurnal elektronik atau biasa disebut dengan E-journal adalah suatu aktifitas yang dilakukan seseorang dalam menggunakan publikasi ilmiah yang berisi hasil penelitian, artikel ilmiah, maupun ringkasan karya akademik, terbit secara berkala melalui online internet maupun CD-ROM.

Motivasi menurut Uno (2017:3) merupakan dorongan yang terdapat dalam diri seseorang untuk berusaha mengadakan perubahan tingkah laku yang lebih baik dalam memenuhi kebutuhannya. Menurut Mc.Donald dalam Sardiman (2016:73) motivasi adalah perubahan energi dalam diri seseorang yang ditandai dengan munculnya "feeling" dan didahului dengan tanggapan terhadap adanya tujuan. 
Dari pengertian yang dikemukakan McDonald ini mengandung tiga elemen penting, yaitu: (1) Motivasi itu mengawali terjadiya energi pada diri seseorang, (2) Motivasi ditandai dengan munculnya rasa atau feeling, (3) Motivasi akan dirangsang karena adanya tujuan. Dengan ketiga elemen diatas maka dapat dikatakan bahwa motivasi akan menyebabkan tejadinya suatu perubahan energi yang ada pada diri seseorang sehingga akan memunculkan rasa untuk kemudian bertindak atau melakukan sesuatu. Semua ini didorong karena adanya tujuan kebutuhan atau keinginan. Dalam buku Psikologi Pendidikan karya Djaali (2014:101), disebutkan bahwa motivasi menurut Sumadi Suryabrata adalah keadaan yang terdapat dalam diri seseorang yang mendorongnya untuk melakukan aktivitas tertentu guna pencapaian suatu tujuan. Sementara Gates mengemukakan bahwa motivasi adalah suatu kondisi fisiologis dan psikologis yang terdapat dalam diri seseorang yang mengatur tindakannya dengan cara tertentu. Adapun Greenberg dalam Djaali (2014:101) menyebutkan bahwa motivasi adalah proses membangkitkan, mengarahkan, dan memantapkan perilaku arah suatu tujuan. Siti suprihatin dalam jurnal pendidikan ekonomi UM Metro mensintesiskan (2015:75) bahwa motivasi dapat diartikan sebagai kekuatan (energi) seseorang yang dapat menimbulkan tingkat kemauan dalam melaksanakan suatu kegiatan. Motivasi dan belajar merupakan dua hal yang saling mempengaruhi. Winkeln dalam Revianandha (2018) menyebutkan motivasi belajar adalah keseluruhan daya penggerak psikis didalam siswa yang menimbulkan kegiatan belajar itu demi mencapai suatu tujuan. Sejalan dengan itu, Sadirman (h.75) mengatakan bahwa motivasi belajar dapat dikatakan sebagai keseluruhan daya penggerak di dalam diri siswa yang menimbulkan kegiatan belajar, sehingga tujuan yang di kehendaki dapat tercapai. Menurut Uno (h.27-28), hakikat motivasi belajar adalah dorongan internal dan eksternal pada para siswa yang sedang belajar untuk mengadakan perubahan tingkah laku, pada umumnya dengan beberapa indikator atau unsur yang mendukung. Motivasi merupakan pendorong bagi mahasiswa untuk melakukan sesuatu. Motivasi menurut Syardiansyah (2016:440) dapat medorong seseorang, sehingga akhirnya orang itu menjadi spesialis dalam bidang ilmu pengetahuan tertentu. Tidak mungkin seseorang mau berusaha mempelajari sesuatu dengan sebaik-baiknya jika ia tidak mengetahui betapa penting dan faedahnya hasil yang akan dicapai dari belajarnya bagi dirinya. Dari beberapa pengertian di atas, maka dapat diambil kesimpulan motivasi belajar adalah dorongan atau daya penggerak psikis yang ada dalam diri siswa yang menimbulkan kegiatan belajar untuk mengadakan perubahan tingkah laku sehingga tujuannya tercapai. 
Indikator atau pengukuran yang dipakai dalam motivasi belajar menurut Uno (h.23) dapat diklasifikasikan sebagai berikut: (1) adanya hasrat dan keinginan berhasil; (2) adanya dorongan dan kebutuhan dalam belajar; (3) adanya harapan dan cita-cita masa depan; (4) adanya penghargaan dalam belajar; (5) adanya kegiatan yang menarik dalam belajar; (6) adanya lingkungan belajar yang kondusif sehingga memungkinkan seseorang siswa dapat belajar dengan baik. Rujukan penelitian terdahulu dalam penelitian ini diantaranya: 1) Jurnal Ibnu Rusydi (2014: 200-210) yang diterbitkan dalam Jurnal Iqra' Volume 08 No.02 di Universitas Hasanudin Makasar, dengan judul Pemanfaatan EJournal Sebagai Media Informasi Digital. 2) Jurnal Supriadi (2015:127 139) yang diterbitkan dalam Lantanida Journal, Vol. 3 No. 2, Tahun 2015 di UIN Ar-Raniry Banda Aceh, dengan judul Pemanfaatan Sumber Belajar Dalam Proses Pembelajaran. 3) Jurnal Nopinia Dwi Kurnia Wati (h.111)yang diterbitkan oleh Program Studi Pendidikan Ekonomi FKIP UNTAN, dengan judul Hubungan Pemanfaatan Sumber Belajar Dengan Motivasi Belajar Mata Pelajaran Ekonomi Siswa Kelas XI SMA. 4) Skripsi Henti Lesviani (2018) yang diterbitkan di UIN Syarif Hidayatullah Jakarta, dengan judul Pemanfaatan Koleksi E-Journal oleh Mahasiswa pada Perpustakaan Fakultas Ekonomi dan Bisnis (FEB) Universitas Muhammadiyah Prof. DR. Hamka (UHAMKA), 5) Skripsi Aminatuz Zuhro (2011) yang diterbitkan di Stikes Aisyiyah Yogyakarta, dengan judul Hubungan Pemanfaatan Fasilitas Internet Dengan Motivasi Belajar dan Prestasi Belajar pada Mahasiswa DIII Kebidanan Semester IV Di Asrama Stikes 'Aisyiyah Yogyakarta.

\section{Hipotesis Penelitian}

Berdasarkan landasan teori dan kerangka berfikir yang telah diuraikan diatas, maka sesuai dengan permasalahan dan tujuan penelitian dapatlah diajukan hipotesis sebagai berikut:1) Diduga terdapat hubungan positif dan signifikan antara pemanfaatan e-journal dengan kemampuan pengetahuan kepustakaan para mahasiswa Fakultas Kesehatan Universitas Mohammad Husni Thamrin, 2) Diduga terdapat hubungan positif antara motivasi belajar mahasiswa dengan kemampuan pengetahuan kepustakaan para mahasiswa Fakultas Kesehatan Universitas Mohammad Husni Thamrin, 3) Diduga terdapat hubungan positif antara pemanfaatan e-journal dan motivasi belajar mahasiswa secara bersama-sama dengan kemampuan pengetahuan kepustakaan para mahasiswa Fakultas Kesehatan Universitas Mohammad Husni Thamrin. 


\section{METODELOGI}

Penelitian ini dilaksanakan di Universitas Mohammad Husni Thamrin Jakarta Timur, khususnya pada mahasiswa program sarjana pada Fakultas Kesehatan. Yaitu program studi S1 Gizi, S1 Keperawatan, dan S1 Kesehatan Masyarakat angkatan ketiga. Dan Universitas Darma Persada Jakarta Timur, khususnya

pada mahasiswa program sarjana pada Fakultas Ekonomi. Yaitu program studi S1 Manajemen dan S1 Akuntansi angkatan ketiga.

Waktu Penelitian dilaksanakan mulai bulan Juni 2018 sampai dengan September 2018.

Metode yang digunakan dalam penelitian ini adalah metode survey dengan pendekatan korelasional

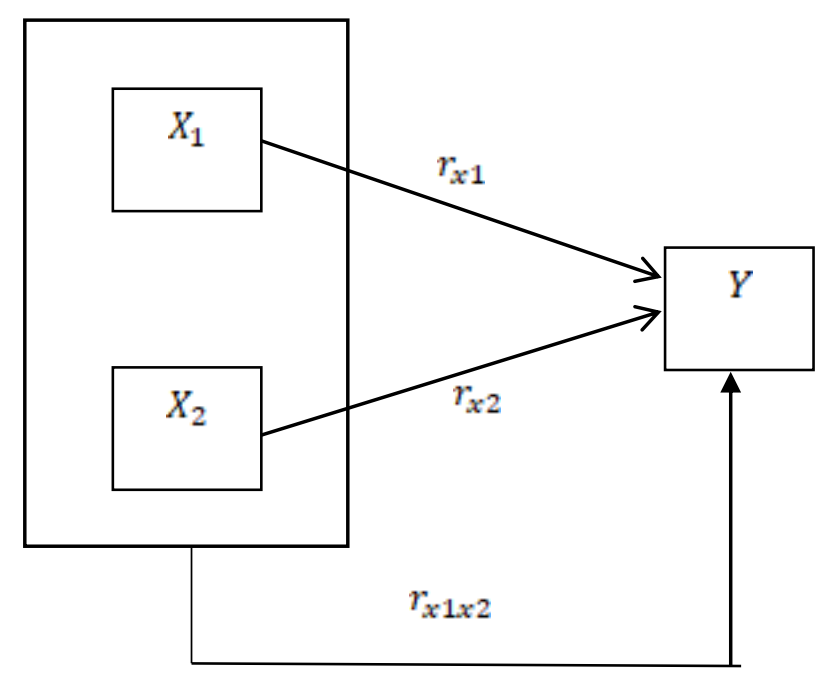

Gambar 2. Desain Penelitian

dimana $Y$ adalah Variabel terikat (kemampuan pengetahuan kepustakaan)

$X_{1}$ adalah Variabel bebas satu (pemanfaatan e-journal), $X_{2}$ adalah Variabel bebas dua (motivasi belajar), $r_{x=1}$ adalah koefisien korelasi antara pemanfaatan $e^{-}$ journal dengan kemampuan pengetahuan kepustakaan, $r_{x 2}=$ Koefisien korelasi antara motivasi belajar dengan kemampuan pengetahuan kepustakaan, $r_{x 1 x 2}$ adalah Koefisien korelasi antara pemanfaatan e-journal dan motivasi belajardengan kemampuan pengetahuan kepustakaan

Adapun teknik analisis data dalam penelitian ini adalah analisis deskriptif dan inferensial. Penulis melakukan penelitian di dua Universitas dikarenakan dari lima Universitas yang memanfaatkan E-Journal dari Kemenristekdikti didapat hanya ada dua Universitas yang memberikan edukasi berupa bimbingan dan teknologi dalam memanfaatkan E-Journal yaitu Universitas Mohammad Husni Thamrin, dan Universitas Darma Persada. Dengan populasi mahasiswa semester enam dari kedua Universitas tersebut yang kesemuanya berjumlah 285 . Teknik pengambilan sampel dalam penelitian ini akan menggunakan teknik 
random sampling, Jumlah sampel dalam penelitian ini didapat dengan menggunakan perhitungan dengan rumus Slovin

Pada uji coba instrumen ini peneliti mengambil populasi sebanyak 119 orang, dengan perhitungan yang sama dengan perhitungan penentuan sampel penelitian yaitu menggunakan rumus Slovin. Berdasarkan perhitungan dengan menggunakan spss versi 21 , dari variabel kemampuan pengetahuan kepustakaan didapat hasil bahwa semua butir pernyataan dinyatakan valid yaitu sebanyak 25 butir pernyataan.

Pengujian reliabilitas instrumen pada penelitian ini menggunakan rumus Alpha Cronbach. Berdasarkan hasil uji reliabilitas dengan menggunakan SPSS 21, didapat hasil bahwa data yang didapat dari angket uji coba dari variabel kemampuan pengetahuan kepustakaan dinyatakan reliabel dengan tingkat indeks sangat tinggi karena rhitung sebesar 0,915 dan rtabel sebesar 0,207 jadi 0,915 > 0,207.

Berdasarkan perhitungan dengan menggunakan spss versi 21, dari variabel pemanfaatan E-Journal didapat hasil bahwa butir pernyataan yang dinyatakan valid yaitu sebanyak 31 butir pernyataan dan jumlah pernyataan yang tidak valid adalah sebanyak 4 nomor. Yaitu nomor 2, 3, 4, 20.

Pengujian reliabilitas instrumen kemampuan pengetahuan kepustakaan pada penelitian ini menggunakan rumus Alpha Cronbach. Berdasarkan hasil uji reliabilitas dengan menggunakan SPSS 21, didapat hasil bahwa data yang didapat dari angket uji coba dari variabel kemampuan pengetahuan kepustakaan dinyatakan reliabel dengan tingkat indeks sangat tinggi karena rhitung sebesar 0,832 dan rtabel sebesar 0,207 jadi 0,832 > 0,207 .

Berdasarkan perhitungan dengan menggunakan spss versi 21, dari variabel motivasi belajar didapat hasil bahwa butir pernyataan yang dinyatakan valid yaitu sebanyak 28 butir pernyataan dan jumlah pernyataan yang tidak valid adalah sebanyak 7 nomor. Yaitu nomor 8, 13, $17,20,22,23,32$.

Berdasarkan hasil uji reliabilitas dengan menggunakan SPSS 21, didapat hasil bahwa data yang didapat dari angket uji coba dari variabel kemampuan pengetahuan kepustakaan dinyatakan reliabel dengan tingkat

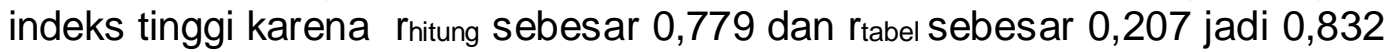
$>0,207$.

\section{HASIL}

Uji Normalitas Kemampuan Pengetahuan Kepustakaan (Y)

Berdasarkan hasil uji Kolmogorov-Smirnov Test terlihat bahwa nilai signifikansi variabel kemampuan pengetahuan kepustakaan adalah

93 I AkademikaJurnal TeknologiPendidikan Vol. 8 No. 2 
sebesar 0,133 yang artinya lebih besar dari nilai probabilitas $(0,05)$, maka dapat dikatakan $\mathrm{H}_{0}$ diterima. Dari hasil tersebut dapat disimpulkan bahwa variabel kemampuan pengetahuan kepustakaan berdistribusi normal pada taraf kepercayaan $95 \%$.

\section{Uji Normalitas Pemanfaatan E-Journal $\left(\mathrm{X}_{1}\right)$}

Hasil uji Kolmogorov-Smirnov Test terlihat bahwa nilai signifikansi variabel kemampuan pengetahuan kepustakaan adalah sebesar 0,050 yang artinya sama dengan nilai probabilitas $(0,05)$, maka dapat dikatakan $\mathrm{H}_{0}$ diterima. Dari hasil tersebut dapat disimpulkan bahwa variabel pemanfaatan E-Journal berdistribusi normal pada taraf kepercayaan 95\%.

Uji Normalitas Motivasi Belajar $\left(\mathrm{X}_{2}\right)$

Hasil uji Kolmogorov-Smirnov Test diatas terlihat bahwa nilai signifikansi variabel motivasi belajar adalah sebesar 0,101 yang artinya lebih besar dari nilai probabilitas $(0,05)$, maka dapat dikatakan $\mathrm{H}_{0}$ diterima. Dari hasil tersebut dapat disimpulkan bahwa variabel motivasi belajar berdistribusi normal pada taraf kepercayaan 95\%.

\section{Uji Homogenitas Pengetahuan Kemampuan Pengetahuan (Y) Terhadap} Pemanfaatan E-Journal $\left(\mathrm{X}_{1}\right)$

Nilai signifikansi kemampuan pengetahuan kepustakaan terhadap pemanfaatan e-journal adalah sebesar 0,60 yang artinya lebih besar dari nilai probablitas sebesar 0,05 . Karena kriteria pengujian data dikatakan homogen apabila nilai signifikansi $>$ nilai probabilitas $(0,05)$, maka keputusan dari pengujian homogenitas dalam variabel ini adalah data berasal dari populasi yang homogen.

Uji Homogenitas Pengetahuan Kemampuan Pengetahuan (Y) Terhadap Motivasi Belajar $\left(\mathrm{X}_{2}\right)$

Hasil perhitungan uji homogenitas pada variabel kemampuan pengetahuan kepustakaan terlihat bahwa nilai signifikansi adalah sebesar 0,85 yang artinya lebih besar dari nilai probablitas sebesar 0,05 . Karena kriteria pengujian data dikatakan homogen apabila nilai signifikansi > nilai probabilitas $(0,05)$, maka keputusan dari pengujian homogenitas dalam variabel ini adalah data berasal dari populasi yang homogen.

\footnotetext{
Uji Linearitas Pengetahuan Kemampuan Pengetahuan (Y) Terhadap Pemanfaatan E-Journal $\left(\mathrm{X}_{1}\right)$

Hasil pengolahan data pengujian signifikansi dan linearitas pengetahuan kemampuan kepustakaan ( $Y$ ) terhadap pemanfaatan $e$ journal $\left(X_{1}\right)$ diketahui bahwa nilai Sig. deviation from linearity sebesar $0.353>0.05$, maka dapat disimpulkan bahwa terdapat hubungan yang linear antara pemanfaatan e-journal dengan kemampuan pengetahuan kepustakaan.
} 
Uji Linearitas Pengetahuan Kemampuan Pengetahuan ( $\mathrm{Y}$ ) Terhadap Motivasi Belajar $\left(\mathrm{X}_{2}\right)$

Hasil pengolahan data pengujian signifikansi dan linearitas pengetahuan kemampuan kepustakaan $(\mathrm{Y})$ terhadap motivasi belajar $\left(\mathrm{X}_{2}\right)$ memperlihatkan nilai Sig. deviation from linearity sebesar $0.087>0.05$, maka dapat disimpulkan bahwa terdapat hubungan yang linear antara motivasi belajar dengan kemampuan pengetahuan kepustakaan.

Adapaun uji hipotesis nya sebagai berikut:

1. Uji Hipotesis Pertama

Hipotesis pertama berbunyi terdapat hubungan antara pemanfaatan e-journal $\left(X_{1}\right)$ dengan kemampuan pengetahuan kepustakaan $(Y)$. Pengujian hipotesis ini menggunakan analisis regresi sederhana. Untuk menguji hipotesis ini dikemukakan hipotesis nol bahwa tidak terdapat hubungan positif antara kedua variabel $(\beta=0)$ lawan hipotesis alternatif $\left(H_{a}\right)$ terdapat hubungan positif antara kedua variabel $(\beta \neq 0)$. Untuk menguji ini dikemukakan bahwa hipotesis nol jika model regresi linier sederhana tidak dapat digunakan untuk memprediksi kemampuan pengetahuan kepustakaan yang dipengaruhi oleh pemanfaatan e-journal, sedangkan hipotesis alternatif jika model regresi linier sederhana dapat digunakan untuk memprediksi kemampuan pengetahuan kepustakaan yang dipengaruhi oleh pemanfaatan e-journal. Kaidah pengujian berdasarkan perbandingan antara $F_{\text {hitung }}$ dan $F_{\text {tabel }}$ yaitu jika $F_{\text {hitung }}<F_{\text {tabel }}$ maka $H_{0}$ diterima, sedangkan jika $F_{\text {hitung }}>F_{\text {tabel }}$ maka $H_{0}$ ditolak. Sedangkan kaidah nilai probabilitas jika nilai signifikansi $>0,05$ maka $H_{0}$ diterima, sebaliknya jika nilai signifikansi $<0,05$ maka $H_{0}$ ditolak. Adapun hasil perhitungannya dapat dilihat pada tabel 1 berikut. 
Tabel 1. Anova untuk Regresi Linier $\boldsymbol{X}_{\mathbf{1}}$ dan $\mathrm{Y}$

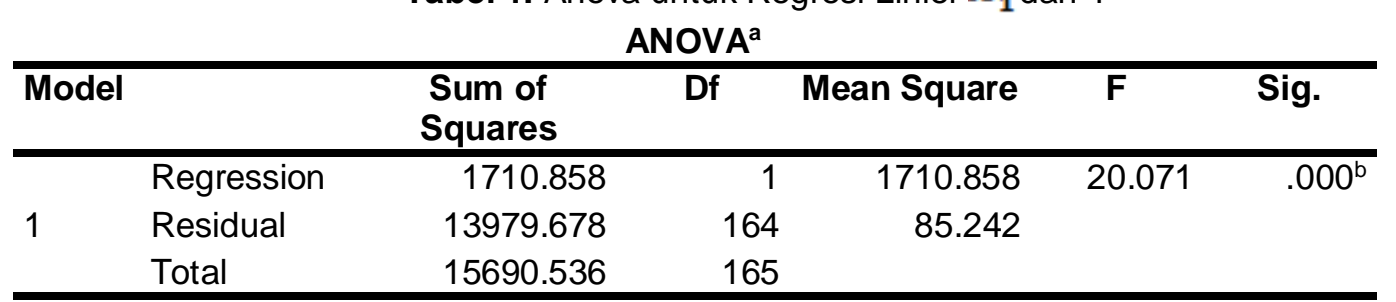

a. Dependent Variable: Pengetahuan_Kepustakaan

b. Predictors: (Constant), Pemanfaatan_Ejournal

Berdasarkan tabel diatas diketahui harga $F_{\text {hitung }}$ adalah sebesar 20,071, sedangkan $F_{\text {tabel }}$ adalah sebesar 3,90. Karena $F_{\text {hitung }}>F_{\text {tabel }}(20,071>3,90)$ maka $H_{0}$ ditolak. Hal ini juga terlihat dari nilai signifikansinya sebesar 0,000 terlihat bahwa nilai tersebut lebih kecil dari nilai probabilitasnya $(0,000<0,005)$ maka $H_{0}$ ditolak. Dari keterangan diatas menunjukkan bahwa koefisien arah regresi $Y$ atas $X_{1}$ signifikan pada taraf 0,05 yaitu model regresi linier sederhana dapat digunakan untuk memprediksi hubungan kemampuan pengetahuan kepustakaan dan pemanfaatan e-journal.

Bentuk hubungan antara kemampuan pengetahuan kepustakaan dengan pemanfaatan e-journal ditunjukkan dengan persamaan regresi $\bar{Y}=64.354+0.303 X_{1}$ sebagaimana yang ditunjukkan oleh tabel 2 Berikut:

Tabel 2. Uji Signifikansi Koefisien Regresi Pengetahuan Kemampuan Kepustakaan ( $Y$ )

Terhadap Pemanfaatan E-Journal $\left(\mathrm{X}_{1}\right)$

\section{Coefficients $^{\mathrm{a}}$}

\begin{tabular}{|c|c|c|c|c|c|}
\hline \multirow[t]{2}{*}{ Model } & \multicolumn{2}{|c|}{$\begin{array}{l}\text { Unstandardized } \\
\text { Coefficients }\end{array}$} & $\begin{array}{l}\text { Standardized } \\
\text { Coefficients }\end{array}$ & $\mathbf{T}$ & Sig. \\
\hline & B & Std. Error & Beta & & \\
\hline (Constant) & 64.354 & 6.591 & & 9.765 & .000 \\
\hline $\begin{array}{l}\text { Pemanfaatan_Ejourn } \\
\text { al }\end{array}$ & .303 & .068 & .330 & 4.480 & .000 \\
\hline
\end{tabular}

a. Dependent Variable: Pengetahuan_Kepustakaan

Persamaan regresi yabel 2 di atas dapat diartikan bahwa untuk setiap kenaikan 1 unit pemanfaatan e-journal diikuti pula oleh kenaikan skor pengetahuan kemampuan kepustakaan sebesar 0,303 unit dengan konstanta 64,354 . Persamaan regresi $\bar{Y}=64.354+0.303 X_{1}$ yang digunakan sebagai dasar untuk memperkirakan hubungan kemampuan pengetahuan kepustakaan yang dipengaruhi oleh pemanfaatan e-journal akan diuji apakah valid. Untuk menguji kevalidan persamaan regresi digunakan dua cara yaitu uji $t$ dan berdasarkan teknik probabilitas. Untuk menguji hipotesis ini dikemukakan bahwa $H_{0}$ tidak terdapat hubungan antara kemampuan pengetahuan kepustakaan dengan pemanfaatan e-journal, $H_{a}$ terdapat hubungan antara kemampuan pengetahuan kepustakaan dengan pemanfaatan e-journal.

Perhitungan uji $\mathrm{t}$ apabila dilihat dalam tabel maka $t_{\text {hitung }}>t_{\text {tabel }}$. $t_{\text {hitung }}$ diketahui sebesar 4,480 , sedangkan $t_{\text {tabel }}$ didapat sebesar 1,97453 dengan perhitungan $t_{\text {tabel }}=\alpha / 2 ; n-k-1$ maka $0,05 / 2 ; 166-1-1$ didapat hasil 0,$025 ; 164$. Maka $H_{a}$ teruji kebenarannya dan dapat diterima yaitu terdapat 
hubungan antara kemampuan pengetahuan kepustakaan dengan pemanfaatan e-journal. Atau dengan kata lain semakin tinggi pemanfaatan e-journal maka semakin tinggi pula kemampuan pengetahuan kepustakaan yang dimiliki oleh para mahasiswa.

Koefisien korelasi didapat dengan analisis korelasi, sedangkan pengujian keberartiannya menggunakan uji t, $H_{0}$ ditolak apabila $t_{\text {hitung }}>t_{\text {tabel }}$ dimana $t_{\text {tabel }}$ dengan derajat bebas $\mathrm{n}-2=166-2=164$ pada taraf signifikansi 0,05 untuk satu sisi kanan adalah $t_{\text {tabel }}=1,97462$.

Hasil perhitungan mengenai hubungan antara kemampuan pengetahuan kepustakaan dengan pemanfaatan e-journal ditunjukkan oleh koefisien korelasi $r_{y 1}$ sebesar 0.330. Untuk menguji keberartian koefisien regresi $Y$ atas $X_{1}$ tersebut dilakukan uji t yang menghasilkan $t_{\text {hitung }}$ sebesar 4,480. Sedangkan $t_{\text {tabal }}$ sebesar 1,97453. Koefisien korelasi signifikan karena $t_{\text {hitung }}>t_{\text {tabel }}$ $(4,480>1,97453)$ sehingga hipotesis nol ditolak. Karena hipotesis penelitian yang menyatakan "terdapat hubungan positif dan signifikan antara pemanfaatan e-journal dengan kemampuan pengetahuan kepustakaan para mahasiswa" teruji dan diterima.

Dengan mengkuadratkan koefisien korelasi $r_{y 1}=0,330$ didapatkan koefisien determinasi $r_{y 1}^{2}=0,109$ yang menunjukkan bahwa pemanfaatan $e$ journal menyumbang 10,9 \% terhadap variasi didalam kemampuan pengetahuan kepustakaan.

Tabel 3. Koefisien Korelasi antara $Y$ dengan $\boldsymbol{X}_{\mathbf{1}}$ Model

Summary

\begin{tabular}{lrrrr}
\hline Model & $\mathbf{R}$ & $\mathbf{R}$ Square & $\begin{array}{c}\text { Adjusted R } \\
\text { Square }\end{array}$ & $\begin{array}{l}\text { Std. Error of } \\
\text { the Estimate }\end{array}$ \\
\hline 1 & $.330^{\mathrm{a}}$ & .109 & .104 & 9.233 \\
\hline a. Predictors: (Constant), Pemanfaatan_Ejournal
\end{tabular}

Selanjutnya untuk mengetahui signifikan atau tidaknya hubungan antara kedua variabel dengan mengontrol pengaruh motivasi belajar dilakukan analisis korelasi parsial, $H_{0}$ ialah tidak terdapat hubungan secara signifikan antara pemanfaatan e-journal dengan kemampuan pengetahuan kepustakaan jika motivasi belajar tetap. $H_{a}$ ialah terdapat hubungan secara signifikan antara pemanfaatan e-journal dengan kemampuan pengetahuan kepustakaan jika motivasi belajar tetap. Dalam penelitian ini pengujian menggunakan uji dua sisi dengan tingkat signifikansi $5 \%$. Tingkat signfikansi dalam hal ini berarti kita mengambil resiko salah dalam mengambil keputusan untuk menolak hipotesis yang benar sebanya-banyaknya $5 \%$. Perhitungan koefisien korelasi parsial antara $X_{1}$ dan $Y$ dengan $X_{2}$ dikotnrol dengan hasil seperti dibawah ini. 
Tabel 4. Koefisien Korelasi Parsial Antara $\boldsymbol{X}_{1}$ dan $\boldsymbol{Y}$ dengan $\boldsymbol{X}_{2}$ dikontrol Correlations

\begin{tabular}{llrrr}
\hline & Control Variables & $\begin{array}{c}\text { Pengetahua } \\
\text { n_Kepustak } \\
\text { aan }\end{array}$ & $\begin{array}{r}\text { Pemanfaata } \\
\text { n_Ejournal }\end{array}$ \\
\hline \multirow{5}{*}{ Motivasi_Belajar } & Pengetahuan & Correlation & 1.000 & .329 \\
& n Kepustakaaa & Significance (2-tailed) &. & .000 \\
& df & Correlation & .329 & 163 \\
& Pemanfaatan & Significance (2-tailed) & .000 & 1.000 \\
& -Ejournal & Df & 163 & 0 \\
\hline
\end{tabular}

a. Cells contain zero-order (Pearson) correlations.

Dari analisis korelasi parsial terlihat bahwa dengan mengontrol (membiarkan tetap pengaruh) motivasi belajar $r_{x 1, x 2, y}=0,329$. Hal ini menunjukkan bahwa terjadi hubungan yang lemah antara pemanfaatan ejournal dengan kemampuan pengetahuan kepustakaan jika motivasi belajar dibuat tetap. Sedangkan arah hubungan adalah positif karena nilai $r$ positif, artinya semakin tinggi pemanfaatan e-journal maka semakin meningkat kemampuan pengetahuan kepustakaan. Selanjutnya uji signifikansi koefisien korelasi parsial digunakan untuk menguji apakah hubungan yang terjadi itu berlaku untuk populasi (dapat digeneralisasi).

Nilai signifikan yaitu $P$ value $(0,000<0,025)$ artinya bahwa terdapat hubungan secara signfikan antara pemanfaatan e-journal dengan kemampuan pengetahuan kepustakaan, jika motivasi belajar dibuat tetap. Hal ini menunjukkan bahwa pemanfaatan e-journal memberikan pengaruh independent, terlepas dari pengaruh motivasi belajar terhadap kemampuan pengetahuan kepustakaan. Jadi dalam penelitian ini dapat disimpulkan bahwa pemanfaatan e-journal berhubungan dengan kemampuan pengetahuan kepustakaan. berikut:

Keberartian koefisien korelasi parsial dapat diuji dengan uji-t sebagai

$$
t_{h Y 1,2}=\frac{r_{y 1,2} \sqrt{n-1}}{\sqrt{1}-r_{y 1,2}^{2}}=\frac{4,20}{0,95}=4,43
$$

Diketahui $t_{\text {tabel }}=1,97462$, karena $t_{\text {hitung }}>t_{\text {tabel }}$ yaitu $4,43>1,97462$ maka $H_{0}$ ditolak dan disimpulkan korelasi antara pemanfaatan e-journal dengan kemampuan pengetahuan kepustakaan jika motivasi belajar dikendalikan sebesar 0,329 tergolong lemah. Dengan tingkat signifikansi korleasi tersebut memberikan kesimpulan bahwa "dengan mengendalikan motivasi belajar, terdapat hubungan yang berarti anatar pemanfaatan e-journal dengan kemampuan pengetahuan kepustakaan".

\section{Uji Hipotesis Kedua}

Hipotesis kedua berbunyi terdapat hubungan antara motivasi belajar $\left(X_{2}\right)$ dengan kemampuan pengetahuan kepustakaan $(\mathrm{Y})$. Pengujian hipotesis ini menggunakan analisis regresi sederhana. Untuk menguji hipotesis ini dikemukakan hipotesis nol bahwa tidak terdapat hubungan positif antara kedua variabel $(\beta=0)$ lawan hipotesis alternatif $\left(H_{a}\right)$ terdapat hubungan positif antara kedua variabel $(\beta \neq 0)$. Untuk menguji ini dikemukakan bahwa hipotesis nol jika 
model regresi linier sederhana tidak dapat digunakan untuk memprediksi kemampuan pengetahuan kepustakaan yang dipengaruhi oleh motivasi belajar, sedangkan hipotesis alternatif jika model regresi linier sederhana dapat digunakan untuk memprediksi kemampuan pengetahuan kepustakaan yang dipengaruhi oleh motivasi belajar.

Kaidah pengujian berdasarkan perbandingan antara $F_{\text {hitung }}$ dan $F_{\text {tabel }}$ yaitu jika $F_{\text {hitung }}<F_{\text {tabel }}$ maka $H_{0}$ diterima, sedangkan jika $F_{\text {hitung }}>F_{\text {tabel }}$ maka $H_{0}$ ditolak. Sedangkan kaidah nilai probabilitas jika nilai signifikansi $>0,05$ maka $H_{0}$ diterima, sebaliknya jika nilai signifikansi $<0,05$ maka $H_{0}$ ditolak. Adapun hasil perhitungannya dapat dilihat pada tabel 5 berikut.

Tabel 5.Anova untuk Regresi Linier $\boldsymbol{X}_{\mathbf{2}}$ dan $\mathrm{Y}$

\begin{tabular}{|c|c|c|c|c|c|c|}
\hline \multicolumn{7}{|c|}{ ANOVA $^{a}$} \\
\hline Model & & $\begin{array}{l}\text { Sum of } \\
\text { Squares }\end{array}$ & Df & Mean Square & $\mathbf{F}$ & Sig. \\
\hline \multirow{3}{*}{1} & Regression & 20.071 & 1 & 20.071 & .210 & $.647^{b}$ \\
\hline & Residual & 15670.465 & 164 & 95.552 & & \\
\hline & Total & 15690.536 & 165 & & & \\
\hline
\end{tabular}

a. Dependent Variable: Pengetahuan_Kepustakaan

b. Predictors: (Constant), Motivasi_Belajar

Berdasarkan tabel diatas diketahui harga $F_{\text {hitung }}$ adalah sebesar 0,210, sedangkan $F_{\text {tabel }}$ adalah sebesar 3,90. Karena $F_{\text {hitung }}<F_{\text {tabel }}(0,210<3,90)$ maka $H_{0}$ diterima. Hal ini juga terlihat dari nilai signifikansinya sebesar 0,647 terlihat bahwa nilai tersebut lebih besar dari nilai probabilitasnya $(0,647>$ $0,005)$ maka $H_{0}$ diterima. Dengan kata lain dapat disimpulkan bahwa $H_{a}$ ditolak, atau tidak terdapat hubungan positif antara kemampuan pengetahuan kepustakaan dengan motivasi belajar. Oleh karena hipotesis yang diajukan ditolak maka pengujian lainnya tidak perlu dilanjutkan.

\section{Uji Hipotesis Ketiga}

Hipotesis ketiga berbunyi terdapat hubungan antara pemanfaatan $e-$ journal dan motivasi belajar secara simultan dengan kemampuan pengetahuan kepustakaan. Pengujian hipotesis ini menggunakan analisis regresi berganda. Untuk menguji hipotesis ini dikemukakan hipotesis nol bahwa tidak terdapat hubungan positif antara kedua variabel bebas dengan variabel terikat $(\beta=0)$ lawan hipotesis alternatif $\left(H_{a}\right)$ terdapat hubungan positif antara kedua variabel bebas dengan variabel terikat $(\beta \neq 0)$. Koefisien korelasi berganda didapatkan dari analisis regresi ganda, sedangkan pengujian signifikansinya dengan uji F.

Selanjutnya dilakukan pengujian hipotesis ketiga dengan uji F. $H_{0}$ ditolak apabila $F_{\text {hitung }}>F_{\text {tabel }}$ dimana $F_{\text {tabel }}$ adalah 3,90. Hasil pengujian hipotesis ini disajikan dalam tabel 6 berikut:

Tabel 6. Anova untuk Regresi Linier $\boldsymbol{X}_{1}, \boldsymbol{X}_{2}$ dan $Y$

ANOVA $^{\mathrm{a}}$

\begin{tabular}{llccccc}
\hline \multicolumn{2}{c}{ Model } & $\begin{array}{c}\text { Sum of } \\
\text { Squares }\end{array}$ & Df & Mean Square & F & Sig. \\
\hline 1 & Regression & 1712.586 & 2 & 856.293 & 9.985 & $.000^{\mathrm{b}}$
\end{tabular}




\begin{tabular}{llll}
\hline Residual & 13977.950 & 163 & 85.754 \\
Total & 15690.536 & 165 & \\
\hline
\end{tabular}

a. Dependent Variable: Pengetahuan_Kepustakaan

b. Predictors: (Constant), Pemanfaatan_Ejournal, Motivasi_Belajar

Berdasarkan hasil perhitungan statistik diatas didapat harga $F_{\text {hitung }}$ sebesar 9,985. Sedangkan $F_{\text {tabel }}$ 3,90. Karena $F_{\text {hitung }}>F_{\text {tabel }}$ maka hal ini menunjukkan bahwa koefisien arah regresi linear $\bar{Y}=66.348+(-0.024) X_{1}+0.302 X_{2}$ signifikan pada taraf 0,05 dapat dilihat pada tabel 7 berikut ini:

Tabel 7. Uji Signifikansi Regresi Hubungan antara Pemanfaatan E-Journal dan Motivasi Belajar Secara Simultan dengan Kemampuan Pengetahuan Kepustakaan

Coefficients $^{\mathrm{a}}$

\begin{tabular}{|c|c|c|c|c|c|c|}
\hline \multirow{2}{*}{\multicolumn{2}{|c|}{ Model }} & \multicolumn{2}{|c|}{$\begin{array}{l}\text { Unstandardized } \\
\text { Coefficients }\end{array}$} & \multirow{2}{*}{$\begin{array}{c}\begin{array}{c}\text { Standardized } \\
\text { Coefficients }\end{array} \\
\text { Beta }\end{array}$} & \multirow[t]{2}{*}{$\mathbf{t}$} & \multirow[t]{2}{*}{ Sig. } \\
\hline & & B & Std. Error & & & \\
\hline \multirow{3}{*}{1} & (Constant) & 66.348 & 15.522 & & 4.274 & .000 \\
\hline & Motivasi_Belajar & -.024 & .172 & -.011 & -.142 & .887 \\
\hline & Pemanfaatan_Ejournal & .302 & .068 & .329 & 4.443 & .000 \\
\hline
\end{tabular}

a. Dependent Variable: Pengetahuan_Kepustakaan

Perhitungan regresi korelasi ganda antara variabel pemanfaatan $e-$ journal dan motivasi belajar dengan kemampuan pengetahuan kepustakaan menghasilkan korelasi ganda $r_{y 1,2}$ adalah 0,330. Ini menunjukkan bahwa pemanfaatan e-journal dan motivasi belajar secara bersama-sama berhubungan dengan kategori hubungan rendah dengan kemampuan pengetahuan kepustakaan.

Pengujian signifikansi koefisien regresi ganda menghasilkan besaran $F_{\text {hitung }} 9,985$ (lihat tabel 6) sedangkan $F_{\text {tabel }}$ pada taraf signifikansi 0,05 adalah 3,90. Karena $F_{\text {hitung }}>F_{\text {tabel }}$ berarti regresi berganda signifikan. Dengan demikian $H_{a}$ diterima atau teruji kebenarannya. Hal ini menunjukkan bahwa terdapat hubungan antara pemanfaatan e-journal dan motivasi belajar secara bersama-sama dengan kemampuan pengetahuan kepustakaan.

Tabel 8.Uji Signifikansi Korelasi Ganda

Model Summary

\begin{tabular}{|c|c|c|c|c|}
\hline Model & $\mathbf{R}$ & R Square & $\begin{array}{l}\text { Adjusted R } \\
\text { Square }\end{array}$ & $\begin{array}{l}\text { Std. Error of } \\
\text { the Estimate }\end{array}$ \\
\hline 1 & $.330^{a}$ & .109 & .098 & 9.260 \\
\hline
\end{tabular}

Dengan mengkuadratkan koefisien korelasi ganda $R_{y 1,2}=0,330$ didapatkan koefisien determinasi ganda $R_{y 1,2}^{2}=0,109$ yang menunjukkan bahwa secara bersama-sama pemanfaatan e-journal dan motivasi belajar menyumbang $33 \%$ terhadap variabel didalam kemampuan pengetahuan kepustakaan. Koefisien determinasi $r^{2}$ adalah sebesar 0,330 ini menunjukkan bahwa $95 \%$ variasi yang terjadi pada kemampuan pengetahuan kepustakaan dijelaskan oleh pemanfaatan e-journal dan motivasi belajar. 
Tabel 9. Rangkuman Hasil Regresi Linear Berganda

\begin{tabular}{cccccc}
\hline $\boldsymbol{R}_{\boldsymbol{y}}(\mathbf{1}, \mathbf{2})$ & $\boldsymbol{R}_{\boldsymbol{y}}^{\mathbf{2}} \mathbf{( 1 , 2 )}$ & $\mathbf{D f}$ & \multicolumn{2}{c}{ Harga F } & Keterangan \\
\cline { 4 - 5 } & & & Hitung & Tabel & \\
\hline 0,330 & 0,109 & $2: 166$ & 9,985 & 3,90 & \multirow{2}{*}{$\begin{array}{c}\text { Terdapat pengaruh ketiga } \\
\text { variabel }\end{array}$} \\
\hline
\end{tabular}

Dari tabel di atas dapat disimpulkan bahwa $H_{0}$ ditolak, karena $F_{\text {hitung }}>F_{\text {tabel }}$ yaitu $9,985>3,90$ harga $F_{\text {tabel }}$ pada taraf signifikansi 5\% dengan $\mathrm{dk}$ pembilang $=2$ dan $\mathrm{dk}$ penyebut $=\mathrm{n}-\mathrm{k}-1=163$ adalah 3,90 .

\section{PEMBAHASAN}

Setelah dilakukan beberapa uji untuk mendapatkan jawaban dari hasil hipotesis yang dimiliki, maka hasilnya dapat dilihat pada pembahasan berikut.

\section{Hipotesis Pertama}

Berdasarkan kaidah pengujian yaitu jika $F_{\text {hitung }}<F_{\text {tabel }}$ maka $H_{0}$ diterima, sedangkan jika $F_{\text {hitung }}>F_{\text {tabsl }}$ maka $H_{0}$ ditolak. Sedangkan kaidah nilai probabilitas jika nilai signifikansi $>0,05$ maka $H_{0}$ diterima, sebaliknya jika nilai signifikansi $<0,05$ maka $H_{0}$ ditolak. Maka hipotesis pertama mendapatkan hasil $F_{\text {hitung }}>F_{\text {tabel }}(20,071>3,90)$ maka $H_{0}$ ditolak. Hal ini juga terlihat dari nilai signifikansinya sebesar 0,000 terlihat bahwa nilai tersebut lebih kecil dari nilai probabilitasnya $(0,000<0,005)$ maka $H_{0}$ ditolak, yang berarti $H_{a}$ diterima.

Berdasarkan perhitungan uji t maka $t_{\text {hitung }}>t_{\text {tabel }}$ atau $4,480>1,97453$. Maka $H_{a}$ teruji kebenarannya dan dapat diterima yaitu terdapat hubungan antara kemampuan pengetahuan kepustakaan dengan pemanfaatan e-journal. Semakin tinggi pemanfaatan e-journal maka semakin tinggi pula kemampuan pengetahuan kepustakaan yang dimiliki oleh para mahasiswa. Hal ini menunjukkan bahwa untuk memanfaatkan e-journal para mahasiswa membutuhkan skill atau kemampuan pengetahuan kepustakaan.

\section{Hipotesis Kedua}

Berdasarkan kaidah pengujian perbandingan antara $F_{\text {hitung }}$ dan $F_{\text {tabel }}$ yaitu jika $F_{\text {hitung }}<F_{\text {tabel }}$ maka $H_{0}$ diterima, sedangkan jika $F_{\text {hitung }}>F_{\text {tabel }}$ maka $H_{0}$ ditolak. Sedangkan kaidah nilai probabilitas jika nilai signifikansi $>0,05$ maka $H_{0}$ diterima, sebaliknya jika nilai signifikansi $<0,05$ maka $H_{0}$ ditolak. Apabila dilihat dari hasil perhitungan hipotesis harga $F_{\text {hitung }}$ adalah sebesar 0,210, sedangkan $F_{\text {tabel }}$ adalah sebesar 3,90. Karena $F_{\text {hitung }}<F_{\text {tabel }}(0,210<3,90)$ maka $H_{0}$ diterima. Hal ini juga terlihat dari nilai signifikansinya sebesar 0,647 terlihat bahwa nilai tersebut lebih besar dari nilai probabilitasnya $(0,647>$ $0,005)$ maka $H_{0}$ diterima. Dengan kata lain dapat disimpulkan bahwa $H_{a}$ ditolak, atau tidak terdapat hubungan positif antara motivasi belajar dengan kemampuan pengetahuan kepustakaan.

Hasil penelitian ini sangat bertentangan dengan peran motivasi dalam belajar dan pembelajaran. Dalam bukunya Hamzah B. Uno menjelaskan bahwa 
ada beberapa peranan penting dari motivasi dalam belajar dan pembelajaran, diantaranya adalah menentukan hal-hal yang dapat dijadikan penguat belajar. Motivasi dapat berperan dalam penguatan belajar apabila seseorang dihadapkan pada suatu masalah yang memerlukan pemecahan, dan hanya dapat dipecahkan berkat bantuan hal-hal yang pernah dilaluinya. Sebagai contoh seorang siswa akan memecahkan materi matematika dengan bantuan tabel logaritma. Tanpa bantuan tabel itu anak tersebut tidak dapat menyelesaikan tugas matematikanya. Upaya untuk mencari tabel logaritma tersebut merupakan peran motivasi yang dapat menimbulkan penguatan belajar. Sama halnya dengan kebutuhan mahasiswa dalam mengerjakan tugas yang diberikan oleh dosen dengan cara mencari jawaban dengan menggali kemampuan pengetahuan kepustakaan yang dimiliki, juga termasuk peran motivasi yang dapat menimbulkan penguatan belajar.

Sama hal nya dengan penelitian terdahulu yang menghasilkan analisis bahwa terdapat hubungan antara motivasi belajar dengan pemanfaatan perpustakaan, yang artinya apabila para mahasiswa secara aktif memanfaatkan perpustakaan dengan segala koleksi yang ada didalamnya, mereka dengan sendirinya akan memiliki kemampuan pengetahuan kepustakaan yang baik.

Siswa yang memiliki motivasi belajar maka akan serius dan tertarik dalam pembelajaran sehingga siswa mendapatkan hasil belajar yang memuaskan. Sama hal nya dengan mahasiswa yang memiliki motivasi belajar akan memiliki kemampuan pengetahuan kepustakaan yang baik, dengan kemampuan pengetahuan kepustakaan tersebut mahasiswa akan dengan mudah mengerjakan tugas-tugas perkuliahannya sehingga akan mendapatkan hasil belajar memuaskan.

Ada beberapa kemungkinan alasan kenapa $H_{a}$ ditolak, atau tidak terdapat hubungan positif antara motivasi belajar dengan kemampuan pengetahuan kepustakaan. Yaitu antara lain: a)Data dilapangan atau hasil angket tidak mendukung hipotesis, b) Waktu penelitian yang sangat terbatas, c) Agar didapatkan hasil angket yang baik penelitian harus dilakukan berulang kali

Untuk itu besar harapan peneliti agar penelitian ini kelak dapat disempurnakan. Agar hasil hipotesis seiring dengan teori yang ada.

\section{Hipotesis Ketiga}

Berdasarkan hasil perhitungan statistik uji hipotesis ketiga didapat harga $F_{\text {hitung }}$ sebesar 9,985. Sedangkan $F_{\text {tabel }}$ 3,90. Karena $F_{\text {hitung }}>F_{\text {tabel }}$ maka regresi berganda signifikan. Dengan demikian $H_{a}$ diterima atau terdapat hubungan antara pemanfaatan e-journal dan motivasi belajar dengan kemampuan pengetahuan kepustakaan namun dengan tingkat hubungan koefisien korelasi rendah $(0,330)$.

\section{Keterbatasan Penelitian}

Penelitian dengan judul Hubungan antara Pemanfaatan E-Journal dan Motivasi Belajar dengan Kemampuan Pengetahuan Kepustakaan ini berfokus pada pengujian korelasi atau hubungan antara ketiga variabelnya. Untuk keperluan ini, peneliti menggunakan uji analisis regresi, dan uji analisis korelasi dengan menggunakan bantuan SPSS Versi 21. Keterbatasan dalam penelitian ini adalah berhubungan dengan sulitnya peneliti mendapatkan data secara jujur dari hasil angket yang disebar, tingkat keseriusan responden dalam mengisi 
angket, selain itu waktu penelitian yang sangat terbatas, karena seyogyanya penelitian harus dilakukan berulang kali sehingga pengukuran dalam penelitian ini masih dikatakan belum akurat.

\section{KESIMPULAN}

Adapun beberapa kesimpulan yang dapat ditarik adalah sebagai berikut:1) Pemanfaatan e-journal di lingkungan Universitas wilayah Jakarta timur (khususnya Universitas Darma Persada dan Universitas Mohammad Husni Thamrin) mempunyai hubungan positif dengan kemampuan pengetahuan kepustakaan yang mereka miliki. Dari hasil penelitian diketahui semakin tinggi pemanfaatan e-journal maka semakin tinggi pula kemampuan pengetahuan kepustakaan yang dimiliki oleh para mahasiswa. Hal ini menunjukkan bahwa untuk memanfaatkan e-journal para mahasiswa membutuhkan skill atau kemampuan pengetahuan kepustakaan.2) Motivasi belajar para mahasiswa diketahui tidak berhubungan dengan kemampuan pengetahuan kepustakaan yang mereka miliki. Hal ini dibuktikan dengan hasil $F_{\text {hitung }}<F_{\text {tabel }}$, yaitu sebesar 0,210 $<3,90$ maka $H_{0}$ diterima dan $H_{a}$ ditolak, begitu juga terlihat dalam kaidah nilai probabilitas jika nilai signifikansi $>0,05$ maka $H_{0}$ diterima, sebaliknya jika nilai signifikansi $<0,05$ maka $H_{0}$ ditolak., apabila dilihat dalam nilai probabilitas ini $(0,647>0,005)$ maka $H_{0}$ diterima. Yang artinya tidak terdapat hubungan positif antara motivasi belajar dengan kemampuan pengetahuan kepustakaan. 3) Pemanfaatan e-journal dan motivasi

belajar secara bersama-sama berhubungan, karena diketahui $F_{\text {hitung }}>F_{\text {tabel }}$ atau 9,985 $>3,90$. Dengan demikian $H_{a}$ diterima atau saling berhubungan antara pemanfaatan e-journal dan motivasi belajar dengan kemampuan pengetahuan kepustakaan namun dengan tingkat hubungan koefisien korelasi rendah yaitu sebesar 0,330.

\section{DAFTAR PUSTAKA}

A. M.,Sardiman. (2016). Interaksi \& Motivasi Belajar Mengajar. Jakarta : Rajawali Pers.

Andrianty, Etty. (2005). "Pemanfaatan Jurnal Elektronis dan Kemuktahiran Informasi yang Disitir dalam Publikasi Primer", Jurnal Perpustakaan Pertanian, 14(2) : 26.

Azwar, Muhammad. (2017). "Pemanfaatan Jurnal Elektronik Sebagai Sumber Referensi, Dalam Penulisan Skripsi Di Institut Pertanian Bogor." Libraria, $5(1): 8$.

Basuki, Sulistyo. (1993). Pengantar IImu Perpustakaan.Jakarta: Gramedia Pustaka Utama.

Djaali. (2014). Psikologi Pendidikan. Jakarta : Bumi Aksara.

Fauziah, Amni. (2017). "Hubungan Antara Motivasi Belajar dan Minat Belajar Siswa Kelas IV SDN Poris Gaga 05 Kota Tangerang." Jurnal JPSD, 4(1): 48. 
Firdaus, Anisah. (2013). Taksonomi Bloom (Ranah Afektif, Kognitif dan Psikomotor). (http://firdausanisaa.blogspot.com/2013/12/taksonomibloom-ranah-afektif-kognitif.html).

Fraenkel, J.R dan Wellen, N.E. (2008). How to Design and Evaluate Research in Education, NewYork: McGraw Hill.

Harisyah. "Pemanfaatan Jurnal Elektronik oleh Mahasiswa Fakultas Kedokteran Universitas Hasanuddin Makasar." Jurnal IImu Perpustakaan Informasi dan Kearsipan, 1(3):82.

HS, Lasa. (1999). Pengelolaan Terbitan Berseri. Jakarta : Kanisius. https://id.wikipedia.org/wiki/Taksonomi_Bloom Jurnal Promosi : Jurnal Pendidikan Ekonomi UM Metro. 3(1):75.

Kurniasari, Ana. (2014). Pemanfaatan Jurnal Elektronik Terhadap Pemustaka Di Perpustakaan Universitas Gadjah Mada Yogyakarta, (http://digilib.uinsuka.ac.id/15024/1/1220010002_bab-i_iv-atau-v_daftar-pustaka.pdf).

Mirzaqon, Abdi. (2018). "Studi Kepustakaan Mengenai Landasan Teori Dan Praktik Konseling Expressive Writing." Jurnal BK UNE. 8(01).

Reitz. ODLIS: Online Dictionary of Library and Information Scien.

Revianandha, Pratama. (2018). Pengaruh Sikap Siswa Tentang Cara Mengajar Guru Dan Penggunaan Alat Bantu Pembelajaran IPS Terhadap Motivasi Belajar Siswa Smp Kelas VIII Di Kecamatan Godean Tahun Ajaran 2012/ 2013, ( http://eprints.uny.ac.id/21859/6/BAB\%20II.pdf ).

Robbins. (2015). Perilaku Organisasi . Jakarta: Salemba Empat.

Rusydi, Ibnu. (2014). Pemanfaatan E-journal Sebagai Media Informasi Digital, Jurnal lqra', 08( 02): $200-210$.

Rusydi, Ibnu. (2014). Pemanfaatan E-Journal Sebagai Media Informasi Digital, Jurnal lqra' 08(02): 201.

S, Sadirman Arif. (2011). Media Pendidikan: Pengertian, Pengembangan dan Pemanfaatannya . Jakarta : Raja Grafindo Persada.

Sriyanto. (2019). Pengertian Kemampuan, (28 Februari 2019), http://ian43.wordpress.com/2010/12/23/pengertian-kemampuan/

Suprihatin, Siti. (2015). "Upaya Guru Dalam Meningkatkan Motivasi Belajar Siswa."

Syardiansyah. (2016). "Hubungan Motivasi Belajar dan Minat Belajar terhadap Prestasi Belajar Mahasiswa Mata Kuliah Pengantar Manajemen (Studi kasus Mahasiswa Tingkat I EKM A Semester II)." Jurnal Manajemen Dan Keuangan, 5(1): 440.

Uno, Hamzah B. (2006). Teori Mativasi dan Pengukurannya. Jakarta: Bumi Aksara.

Uno, Hamzah B. (2017). Teori Motivasi \& Pengukurannya : Analisis di Bidang Pendidikan . Jakarta : Bumi Aksara.

Zakia, Hafid Dotuz. (2014). Hubungan antara Motivasi Belajar terhadap Pemanfaatan Perpustakaan oleh Siswa MAN 1 Yogyakarta. Skripsi. Program studi IImu Perpustakaan, UIN Sunan Kalijaga, Yogyakarta. 